\title{
MENGHIDUPKAN KESENIAN KETOPRAK DI DESA SANGGRAHAN KECAMATAN KRANGGAN KABUPATEN TEMANGGUNG JAWA TENGAH
}

\author{
YB. Rahno Triyogo \\ Jurusan Pedalangan \\ Fakultas Seni Pertunjukan ISI Surakarta
}

\begin{abstract}
Judul artikel PPM Tematik ini adalah Menghidupkan Kesenian Ketoprak Di Desa Sanggrahan, Kecamatan Kranggan, Kabupaten Temanggung, Jawa Tengah yang memusatkan perhatiannya pada usaha menghidupkan kembali kesenian ketoprak yang pernah ada sebelumnya. Berpijak pada judul artikel di atas dengan mudah dapat ditangkap bahwa yang menjadi tujuan penulisan artikel ini adalah mendiskripsikan usaha-usaha untuk menghidupkan kembali kesenian ketoprak yang pernah ada dan kini dalam keadaan mati suri. Adapun langkah yang ditempuh adalah mengadakan pelatihan untuk para pemain dan pengrawit, serta pembinaan dalam bidang cara-cara berorganisasi. Pelatihan dilakukan dengan mempertimbangkan kualitas dan kuantitas pemain maupun pengrawit, naskah lakon, pelatih, dan waktu atau jaduwal latihan. Adapun materi latihan meliputi membaca naskah lakon, dialog (penguasaan vokabuler bahasa Jawa dan unggah-ungguh), bloking, actions, perang kombat, perang masal, dan make-up. Latihan dilakukan secara maraton, dan menghasilkan sebuah pertunjukan ketoprak dengan durasi waktu 2 jam dengan lakon Manunggal. Lakon disusun oleh Ki Legowo Cipto Karsono, Agus Joko Susilo, dan Rekryandrie Prabaningmas. Sesuai dengan keinginan masyarakat pendukungnya bahwa hasil latihan dipentaskan dalam acara perpisahan mahasiswa KKN dengan warga desa Sanggrahan yang diselenggarakan pada tanggal 27 Agustus 2018.
\end{abstract}

Kata kunci: eksistensi, ketoprak, Sanggrahan Temanggung.

\begin{abstract}
The title of this Thematic dedication to community article is Reviving Ketoprak Art in Sanggrahan, Kranggan, Temanggung, Central Java, which focuses its attention on reviving ketoprak art that had existed before. Based on the title of the article above it can be easily captured that the purpose of writing this article is to describe efforts to revive the art of ketoprak that once existed. The steps taken are conducting training for players and players, as well as coaching in the field of ways to organize. The training is carried out by considering the quality and quantity of players as well as players, script manuscripts, coaches, and time or time of training. The training material includes reading script, dialogue (mastering Javanese vocabulary and uploading), blocking, actions, kombat war, mass warfare, and make-up. The training was conducted in a marathon, and resulted in a ketoprak show with a duration of 2 hours with the Manunggal play. The play was composed by Ki Legowo Cipto Karsono, Agus Joko Susilo, and Rekryandrie Prabaningmas. In accordance with the wishes of the supporting community that the results of the exercise were staged in the farewell program of Community Service Program (KKN) students and residents of Sanggrahan which was held on August 27, 2018.
\end{abstract}

Keywords: existence, ketoprak, Sanggrahan Temanggung. 


\section{LATAR BELAKANG DAN MASALAH}

Temanggung merupakan sebuah kabupaten yang kaya dengan seni tradisi dan budaya. Kehidupan kesenian dan kebudayaan di kabupaten Temanggung sungguh-sungguh mendapat tempat di hati masyarakat, sehingga ada banyak hasil kebudayaan yang terpelihara dengan baik. Berdasarkan pengalaman penulis yang pernah tinggal selama lebih dari 9 tahun di sebuah desa di Kabupaten Temanggung, bahwa unggah-ungguh, sikap tulus dan ramah masyarakat terhadap siapa pun terpelihara dengan baik sejak masa lampau. Berdasarkan pengalaman nyata tersebut, penulis sering mengatakan bahwa ciri khas masyarakat Kabupaten Temanggung adalah sopan, tulus, dan ramah.

Telah disinggung di atas bahwa Kabupaten Temanggung kaya dengan seni dan budaya. Ada beberapa jenis kesenian yang sejak masa lampau terpelihara dengan baik. Beberapa kesenian tersebut misalnya Jaran Kepang yang sering dikenal dengan istilah jaranan. Kecuali Jaran Kepang juga terdapat kesenian Barongan, Topeng Ireng, Srandhul (sandhul), wayang kulit, terbangan, dan teater tradisional yang lebih dikenal sebagai ketoprak. Di antara sekian banyak jenis kesenian, Jaran Kepang merupakan sebuah kesenian yang paling favorit di Kabupaten Temanggung, karena hampir setiap kecamatan mempunyai lebih dari tiga kelompok kesenian Jaran Kepang (wawancara dengan Pawit). Adapun kesenian yang selalu mendampingi atau menyertai Jaran Kepang adalah kesenian Barongan. Hal yang demikian terjadi karena kesenian Barongan selalu muncul bersamaan dengan Jaran Kepang. Khusus mengenai kehidupan kesenian wayang kulit purwa dapat dikatakan bahwa di Temanggung tidak banyak dijumpai kelompok kesenian wayang kulit purwa, tetapi sering dijumpai pertunjukan wayang kulit purwa dengan cara mananggap kelompok kesenian dari luarTemanggung. Pertunjukan wayang purwa yang mereka sukai adalah gaya (gagrag) Yogyakarta, Surakarta, dan Kedu.
Sanggrahan merupakan sebuah desa di Kecamatan Kranggan - Kabupaten Temanggung Jawa Tengah terbagi menjadi 9 dusun yakni Krajan, Gunungpring, Madusari, Losari, Rowowetan, Rowokulon, Tegalombo, Tambaksari, dan Gemawang. Mata pencaharian penduduk umumnya bertani. Desa ini merupakan salah satu penghasil tapioka dan juga ayam ternak. Di Desa Sanggrahan terdapat setidaknya 4 grup Jaran Kepang yang tersebar di 9 dusun. Salah satu grup jaranan yang terkenal adalah Satrio Wibowo dari Dusun Gunungpring. Grup jaranan yang lain adalah kelompok jaranan Dwi Tunggal dari Dusun Tegalombo. Selain berbagai kelompok kesenian, di Sanggrahan juga tinggal seorang dalang senior spesial pakeliran gaya Kedu yakni Ki Legowo Cipto Karsono dari Dusun Rowowetan. Begitu pula dengan kedua putranya yang juga sebagai dalang yaitu Ki Gunawan dan Ki Danas yang juga tinggal di desa Sanggrahan. Gaya pekelian yang dianut kedua puteranya lebih condong ke pakeliran gaya Yogyakarta (Wawancara dengan Jupriyono).

Berdasarkan survei yang dilakukan secara langsung terjun ke masyarakat, juga berdasarkan laporan mahasiswa KKN 2017 yang lalu maka potensi seni budaya yang ada di Desa Kranggan dapat didiskripsikan sebagai berikut:

1. Desa Kranggan mempunyai tiga orang tokoh yang bergerak dalam bidang seni budaya Jawa, yaitu dalang wayang kulit purwa bernama $\mathrm{Ki}$ Legawa Cipto Karsono, dan dua puteranya bernama Ki Gunawan dan Ki Danas. Mereka bertiga merupakan dalang yang masih aktifatau laku, bahkan bisa dikategorikan laris. Ketiganya mempunyai pengaruh penting dalam mengembangkan potensi seni dan budaya di Desa Sanggrahan khususnya dan tingkat kabupaten umumnya.

2. Desa Sanggrahan mempunyai kepala desa dan seketaris desa yang menaruh perhatian cukup besar terhadap seni budaya. Hal itu ditandai dengan setiap tahun diadakan pentas seni budaya dalam rangka peringatan HUT RI, dan kedua 
pejabat desa itulah yang sangat berperan dalam terselenggaranya pesta seni budaya pada setiap tahunnya. Menurut pengakuan Jauhari (Kades Sanggrahan) bahwa pentas seni budaya bukan kehendak pemerintahan desa tetapi atas kehendak masyarakat sendiri. Perangkat desa hanya tutwuri handayani.

3. Terdapat kursus pedalangan yang diselenggarakan di rumah Ki Legawa, dengan guru Ki Legawa dan kedua puteranya.

4. Mempunyai kelompok karawitan dewasa.

5. Mempunyai beberapa MC Jawa (pambyawara). Menurut Jurpiyono bahwa Desa Sanggrahan mempunyai sekitar 9 orang pambyawara.

6. Mempunyai Sekolah Dasar yang mengembangkan kegiatan menari dan drumband.

7. Sekolah Menengah Pertama (SMP) mempunyai kegiatan yang diunggulkan, yaitu kesenian Karawitan.

8. Mempunyai kelompok kesenian Topeng Ireng.

9. Mempunyai kelompok kesenian Gedrug.

10. Mempunyai kelompok kesenian Kuda Lumping (Jaran Kepang, atau Jaranan), dan

11. Mempunyai kelompok teater tadisional Ketoprak.

12. Setiap tahun diselenggarakan pesta seni dan budaya yang diikuti oleh 9 dukuh desa Sanggrahan.

Kesenian-kesenian tersebut dipentaskan setiap tahun secara rutin dalam bentuk pertunjukan bersama dalam rangka peringatan HUT Kemerdekaan RI. Dengan demikian sesungguhnya hampir semua kesenian yang ada di desa Sanggrahan dapat dikatakan hidup. Dari sekian banyak kesenian yang ada di desa Sanggrahan, hanya kesenian ketoprak yang dalam keadaan pasif, dalam arti tidak pernah ada lagi kegiatan berketoprak. Menurut warga desa Sanggrahan bahwa kesenian ketoprak yang sedang mati suri itu penting untuk dihidupkan dari kematiannya. Kesenian ketoprak penting untuk dihidupkan kembali karena merupakan warisan budaya yang masih dianggap bernilai, yang mempunyai 3 aspek, yaitu kebudayaan sebagai tata kelakuan manusia, kebudayaan sebagai kelakuan manusia itu sendiri, dan kebudayaan sebagai hasil kelakuan manusia (Bambang Suwondo, 1981: 6).

\section{TUJUAN}

Judul artikel ini adalah Menghidupkan Kesenian Ketoprak di Desa Sanggrahan. Dari judul dapat diperoleh sekilas informasi bahwa pada masa lampau di Desa Sanggrahan pernah ada kesenian ketoprak, tetapi kemudian fakum untuk sementara waktu. Menurut informasi yang diperoleh bahwa kesenian tesebut hidup kurang lebih selama 20 tahun kemudian sekitar awal tahun 2000-an kesenian ketoprak tersebut disebut telah mengalami kefakuman, yang oleh Jupriyono (Sekdes Sanggrahan) disebut sebagai mati-suri.

Seiring dengan lajunya waktu, pelaku PPM Tematik dan Mahasiswa KKN (2018) ISI Surakarta mendengar secara langsung keinginan masyarakat Desa Sanggrahan untuk menghidupkan kembali kesenian ketoprak yang pernah ada. Berpijak pada keinginan masyarakat Desa Sanggrahan itulah PPM Tematik bersama mahasiswa KKN Desa Sanggrahan menyatakan kesediannya untuk secara bersama-sama dengan masyarakat setempat berusaha menghidupkan kembali kesenian ketoprak yang telah lama dalam keadaan mati suri.

\section{DASAR PEMIKIRAN}

Kesenian tradisional ketoprak merupakan bagian dari hasil kebudayaan manusia Jawa yang layak untuk dihidupkan kembali. Kecuali karena keinginan masyarakat yang bersemangat akan menghidupkan kembali kesenian tradisional ketoprak, peneliti juga melihat arti pentingnya kesenian ketoprak bagimasyarakat pada umumnya. Secara umum kesenian ketoprak berfungsi memberi hiburan atau tontonan, berfungsi pendidikan, sebagai media kritik sosial, menyampaikan pesan- 
pesan pemerintah dalam rangka pembangunan bangsa dan negara, juga sebagai sarana ekspresi. Dengan demikian ketoprak mempunyai multi fungsi. Oleh karena ketoprak mempunyai multi fungsi itulah penelitibersemangat untuk membantu menghidupkan kembali kesenian ketoprak yang sedang dalam keadaan mati-suri ini.

Menghidupkan ketoprak yang sedang dalam mati suribukan merupakan pekerjaan yang mudah. Untuk dapat menghidupkan kembali kesenian ketoprak yang telah mati suri dibutuhkan identifikasi persoalan yang dapat digunakan sebagai pijakan untuk menentukan langkah berikutnya. Proses identifikasi dilakukan pertama, mencari tahu sejarah keberadaan ketoprak di Desa Sanggrahan sejak berdiri sampai keadaan mati-suri. Hal ini penting dilakukan karena dengan mengetahui sejarah kesenian ketoprak tersebut akan dapat diidentifikasi persoalan yang dihadapi dan jalan keluar yang harus dilakukan. Kedua, peneliti sadar benar bahwa untuk dapat menghidupkan kembali kesenian ketoprak diperlukan skill atau keahlian baik yang menyangkut pemain maupun pengrawit. Ketiga, oleh karena yang digarap adalah keahlian atau skill maka wajib diadakan pelatihan secara sungguh-sungguh. Adapun langkah yang dilakukan adalah mengadakan latihan secara terus menerus, berulang-ulang, dan secara maraton.

\section{SEJARAH SINGKAT KESENIAN KETOPRAK DI DESA SANGGRAHAn}

Sejarah kesenian ketoprak di Desa Sanggrahan ini diperoleh melalui wawancara dengan beberapa tokoh Desa Sanggrahan. Bukti tertulis tidak dijumpai karena kehidupan mereka masih sangat tradisional. Segala sesuatunya tidak pernah dicatat sehingga tidak ditemukan bukti tertulis, dengan kata lain mereka lebih mengandalkan kekuatan ingatan. Oleh karena hanya mengandalkan daya ingat itulah maka dapat disebut belum mempunyai managemen yang baik. Cara yang demikian tentu mempunyai banyak kelemahan. Mengenai hal ini Teeuw (1989) mengatakan bahwa orang Indonesia berbeda dengan orang Eropa. Orang Indonesia bersifat kelisanan (mengandalkan kekuatan telinga), sedangkan orang Eropa bersifat keberaksaraan (lebih mengandalkan pembacaan)

Untuk memperoleh gambaran sejarah kesenian ketoprak di desa Sangrahan, diadakan wawancara dengan para tokoh desa yang mengalami kejayaan ketoprak di Desa Sanggrahan, juga wawancara terhadap mantan pemainnya. Adapun tokoh-tokoh yang diwawancarai itu adalah:

1. Ki Legawa Cipto Karsono (63 tahun), seniman dalang wayang kulit purwa gagrag Kedu, sekaligus budayawan dariDusun Rowo Wetan, Desa Sanggrahan.

2. Bapak Jumianto (62 tahun), Kadus Rowo Wetan.

3. Bapak Jupriyono, menjabat sebagai Sekdes (carik) Desa Sanggrahan, dan

4. Bapak Pawit (58 tahun) mantan pemain ketoprak di Desa Sanggrahan yang selalu berperan sebagai pelawak.

Berdasarkan wawancara dengan para tokoh desa tersebut diperoleh gambaran mengenai sejarah kesenian ketoprak di Desa Sanggrahan sebagai berikut.

Bahwa Desa Sanggrahan terdiri dari 9 dusun. Kesenian ketoprak di desa Sanggrahan berpusat di Dusun Rowo Wetan dengan nama Sapta Budaya yang berdiri tahun 1982. Pada awal berdirinya ketoprak Sapta Budaya dipimpin oleh Sarnadi, dengan pelatih tunggalnya bernama Kismo. Seperti halnya organisasi kesenian lainnya kesenian ketoprak Sapta Budaya mengalami beberapa kali pergantian pimpinan. Dari Sanardi beralih kepada Hadi Susila, kemudian diganti oleh Bambang TN, dan terakhir oleh Surawan. Ketoprak Sapta Budaya mempunyai anggota sekitar 50 orang yang terdiri dari pemain dan pengrawit serta beberapa crew. Menurut pengakuan beberapa tokoh desa, ketoprak Sapta Budaya pernah laku, artinya pernah menerima tanggapan dan pentas di desanya sendiri dan tetangga desa dalam acaraacara tertentu. 


\section{Abdi Seni Jurnal Pengabdian Kepada Masyarakat}

Menurut informasi yang diperoleh, bahwa group ketoprak Sapta Budaya mengalami kemunduran setelah Kismo, pelatih tunggalnya pergi meninggalkan Dusun Rowo Wetan berpindah ke luar Jawa. Peristiwa itu terjadi pada awal tahun 2000an. Menyusul kemudian sebagian besar para pemain dan pengrawitnya pindah dari Sanggrahan karena pernikahan dan juga karena alasan pekerjaan yang mengharuskan mereka meninggalkan Desa Sanggrahan. Dengan berpindahnya beberapa pemain dan pengrawit tersebut mengakibatkan pasifnya ketoprak Sapta Budaya.

Menurut Pawit (mantan pemain Sapta Budaya) bahwa kira-kira semenjak awal taun 2000an ketoprak Sapta Budaya mengalami kevakuman, namun demikian sisa para pemainnya masih sempat main ketoprak beberapa kali bersama dengan group ketoprak dari desa lain. Masih menurut Pawit, bahwa pada tahun 2014 beberapa pemuda desa mengadakan pertunjukan kesenian ketoprak dalam acara pernikahan. Pada tahun itulah mereka main untuk yang terakhir kalinya.

Menurut pengakuan beberapa tokoh dikatakan bahwa Sapta Budaya ketika itu sudah dapat dikatakan group ketoprak yang mandiri, artinya bahwa group ketoprak tersebut telah memiliki peralatan lengkap sebagaimana yang dibutuhkan oleh group kesenian ketoprak pada umumnya. Kebutuhan yang dimaksud meliputi jumlah seniman yang cukup memadai, yakni sekitar 50 orang yang terdiri dari pemain dan pengrawit. Kecuali jumlah personil juga ditunjang telah memiliki alat musik karawitan lengkap (pelog dan slendro), kostum, properti, dan pelatih tetap.

Ketika berdialog dengan para tokoh masyarakat setempat saat memberi keterangan, penulis terusik oleh kata-kata yang sering mereka ucapkan, yaitu "kinen-kinten" (kira-kira). Hal itu menunjukkan bahwa mereka masih ragu-ragu dengan keterangan yang mereka berikan. Mereka menjawab sesuai dengan yang mampu mereka ingat. Hal itu menunjukkan bahwa group ketoprak tersebut belum mempunyai tata kelola yang baik, atau belum mempunyai manajemen yang baik. Menurut mereka bahwa pada waktu itu mereka belum menggunakan metode mencatat, semuanya dilakukan secara spontan non tulisan, dan hanya mengandalkan kemampuan ingatan belaka. Harta kekayaan (harta inventaris) group dan susunan kepengurusan pun belum dicatat atau diadministrasikan dengan baik. Oleh karena tidak mempunyai manajemen yang baik itulah maka banyak barang inventaris yang hilang. Ekstrimnya bahwa seperangkat alat musik gamelan yang merupakan peralatan inti tidak diketahui keberadaannya. Begitu pula dengan lakonlakon yang pernah dilakonkan tidak tercatat sehingga ketika ditanya tentang lakon yang pernah dilakonkan merek menjawab dengan kata "lupa".

Menurut pengakuan tokoh pemuda bernama Memo dan Saiful (Ipul), bahwa pemuda Karang Taruna sudah sejak lama berniat menghidupkan kembali ketoprak di desanya. Mereka siap berlatih dan melakukan segala sesuatu demi bangkitnya kembali kesenian ketoprak di desanya. Hal itu ditandai dengan sekitar tahun 2014 dengan modal sangat minim berani mengisi acara pernikahan dengan bemain ketoprak. Yang dimaksud dengan modal dalam hal inimeliputi jumlah pemain yang sangat terbatas, kemampuan pemain yang terbatas pula, serta pengiring yang tebatas. Bersamaan dengan pertunjukan ketoprak pada tahun 2014 tersebut group ketoprak mereka diberi nama Taruna Budaya. Sejak saat itu (2014) nama ketoprak Sapta Budaya tenggelam kemudian muncul nama ketoprak yang baru bernama Taruna Budaya. Dua tahun kemudian ketoprak Taruna Budaya manggung sekali lagi, kemudian tenggelam lagi sampai tahun 2018.

Kehadiran mahasiswa KKN ISI Surakarta 2018 dan PPM Tematis 2018 mampu menyemangati mereka untuk bangkit kembali. Dalam waktu yang singkat mereka belajar bersama mahasiswa KKN 2018 dan PPM Tematik serta didukung keluarga Ki Legawa Cipto Karsono menghasilkan sebuah pertunjukan yang disajikan pada tanggal 27 Agustus dengan lakon MANUNGGAL. 


\section{AWAL KEBANGKITAN KETOPRAK TARUNA BUDAYA}

Kebangkitan ketoprak Taruna Budaya diawali dengan seorang pemuda bernama Memo yang menikah pada tahun 2014. Pada pesta pernikahannya ia menyajikan hiburan kesenian ketoprak yang para pemainnya berasal dari Desa Sanggrahan. Oleh karena kelompok kesenian ketoprak tersebut belum mempunyai nama maka kemudian diberi nama secara spontan, yaitu Taruna Budaya. Ketika ada pertanyaan apakah Taruna Budaya menggantikan ketoprak Sapta Budaya atau merupakan group ketoprak tersendiri?, ia menjelaskan bahwa sebagian pendukung ketoprak Taruna Budaya adalah orang-orang yang dahulu merupakan pendukung ketoprak Sapta Budaya, satu diantaranya yang sampai tahun 2018 ini aktif adalah Pawit. Pawit merupakan salah seorang mantan pemain Sapta Budaya yang selalu berperan sebagai pelawak. Berdasarkan keterangan Memo dan Pawit nama Taruna Budaya merupakan kelanjutan dari Sapta Budaya. Diceritakan oleh Pawit, Memo, dan Jupriyono bahwa sejak tahun 2014 tersebut ketoprak Taruna Budaya baru main satu kali, yaitu pada tahun 2016.

Kehadiran PPM Tematik dan mahasiswa KKN ISI Surakarta (2018) di Desa Sanggrahan mampu membangkitkan semangat para pemuda untuk menghidupkan kembali kesenian ketoprak yang menurut mereka dalam keadaan mati-suri. PPM Tematik dan KKN 2018 segera bergerak dengan mencari informasi yang memungkinkan untuk membantu mereka menghidupkan kembali kesenian ketoprak. Dari observasi yang dilakukan diperoleh gambaran kelebihan dan kekurangannya. Kelebihan dan kekurangan dari masyarakat pendukung ketoprak Taruna Budaya penting dibicarakan dalam rangka menghidupkan kembali ketoprak Taruna Budaya. Dari kelebihan dapat dilihat sisi positifyang mendukung kesiapannya untuk dihidupkan kembali, sedangkan dari sisi kekurangannya dapat diperoleh gambaran mengenai segala sesuatu yang harus dilakukan. Adapun kelebihannya dan kekurangannya sebagai modal utama adalah sebagai berikut.

\section{Kelebihan}

Sesungguhnya kelebihan utama dari ketoprak Taruna Budaya terletak pada para pendukungnya. Yang dimaksud dengan pendukung pada atikel ini bukan hanya hanya pemain, pengiring, dan crewnya saja, tetapi juga meliputi masyarakat, para tetua, dan perangkat desa.

Pawit, sebagai mantan pemain Sapta Budaya merasa pesimis terhadap keinginan kaum muda untuk menghidupkan kembali kesenian ketoprak yang pernah ada. Rasa pesimisnya cukup beralasan karena pertama, para pemuda sebagai pemain inti belum memiliki kemampuan yang memadai, dan belum mempunyai pengalaman sebagai pemain panggung. Mereka masih harus banyak belajar tentang akting, dialog, dannembang. Kedua, dibutuhkan anggaran yang tidak sedikit, karena belum memiliki alat musik gamelan yang lengkap, kostum dan properti. Berbeda dengan Pawit yang pesimis, sebaliknya Jupriyono (Sekdes Sanggrahan) dan para pemuda Karang Taruna yang mempunyai optimisme cukup tinggi. Jupriyono berkeyakinan bahwa tidak sampai dua tahun ketoprak Taruna Budaya akan memiliki seperangkat alat musik gamelan yang lengkap, yaitu pelog dan slendro. Dengan semangat ia berjanji bersama Karang Taruna dan warga desa akan berusaha menghimpun dana untuk membeli seperangkat alat musik gamelan. Ia juga bersedia mencari sponsor guna meraih keinginannya itu. Dari sisi pemuda Karang Taruna sebagian anggotanya bersedia membantu usaha Jupriyono mencari dana guna membeli seperangkat alat musik gamelan. Mereka juga bersedia untuk berlatih baik berlatih musik karawitan maupun menjadi pemainnya.

Desa Sanggrahan mempunyai budayawan yang bisa diandalkan, yaitu Ki Legawa Cipta Karsono (63 tahun). Beliau siap melatih warga yang menyediakan diri belajar karawitan, bahkan alat musik gamelannya diijinkan digunakan untuk latihan. Dengan penuh semangat beliau juga siap untuk menyusun naskah lakon, bahkan rumahnya diijinkan 


\section{Abdi Seni Jurnal Pengabdian Kepada Masyarakat}

untuk tempat latihan. Dengan besarnya semangat Ki Legawa tersebut untuk sementara persoalan alat musik gamelan telah teratasi, begitu pula dengan kesediaannya melatih musik karawitan.

\section{Kekurangan}

Warga desa Sanggrahan sadar akan kekurangannya untuk menghidupkan kembali kesenian ketoprak. Untuk mendirikan sebuah group kesenian khususnya seni pertunjukan sudah dapat dipastikan diperlukan modal yang cukup tinggi. Pengertian modal tidak hanya dibatasi pada soal keuangan, tetapi juga meliputi skil. Modal atau kebutuhan yang harus terpenuhi antara lain meliputi pemain, pengrawit, alat musik pengiring, kostum, properti, dan pelatih (pemain dan pengiring), serta keuangan. Hal-hal pokok tersebut diuraikan sebagai berikut.

a. Pemain dan Pengrawit

Pemain dan pengrawit dalam ketoprak Taruna Budaya mempunyai posisi yang sama. Ketoprak Taruna Budaya belum memiliki pemain dan pengrawit yang siap manggung, dan hanya ada beberapa pemain dan pengrawit sudah lumayan bisa diajak kerja sama. Namun demikian diakui bahwa semangat mereka merupakan modal yang tidak dapat dianggap ringan. Jika ditilik dari sudut pandang semangat mereka (pemain, pengrawit, dan masyarakat pendukung) maka tidak ada keraguan bahwa ketoprak Taruna Budaya dapat bangkit dan berkembang. Khusus mengenai pengrawit, seperti telah disinggung di atas bahwa ketoprak Taruna Budaya belum mempunyai tim pengrawit, namun demikian dalam keadaan genting Ki Legawa akan dapat mengatasi karena sebagai seorang dalang profesional ia telah memiliki team karawitan yang kuat.

Atas dasar keadaan pemain dan pengrawit di atas ada konsekuensi yang harus ditanggung, yaitu melatih mereka dengan sungguh-sungguh sampai terbentuk team karawitan yang baik. Adapun materi latihan dapat disesuaikan dengan bekal kemampuan yang mereka miliki.

\section{b. Kostum dan properti}

Kostum dan propertioleh mereka dianggap tidak ada persoalan, meskipun sampai saat ini mereka belum mempunyai kostum dan properti. Kostum dan properti peninggalan Sapta Budaya sudah tidak ada lagi. Bagi mereka persoalan properti dan kostum akan dengan mudah dapat diatasi. Bagi mereka yang dirasa paling penting dan segera diusahakan adalah memiliki seperangkat alat musik gamelan.

\section{c. Pelatih}

Pelatih merupakan bagian terpenting, apa lagi bagi kesenian ketoprak Taruna Budaya yang baru saja bangkit kembali. Yang dimaksud dengan pelatih dalam hal ini meliputi pelatih untuk pengrawit dan pelatih para aktornya. Untuk pelatih musik pengiring ataupengrawit, Ki Legawa menyediakan diri untuk melatih. Sedangkan pelatih untuk pemain, mereka mempunyai 2 pilihan. Pilihan pertama mereka akan meminta bantuan Prodi Teater ISI Surakarta untuk melatih. Apa bila pilihan pertama gagal karena sesuatu hal maka akan diambil pilihan kedua, yaitu meminta bantuan para mantan mahasiswa yang pernah KKN di Desa Sanggrahan. Dengan demikian untuk sementara persoalanpersoalan dapat teratasi.

\section{LATIHAN DAN HASIL YANG DICAPAI}

Berdasarkan kajian dan pengamatan secara langsung mengenai potensi pemuda Karang Taruna dan masyarakat pendukungnya maka PPM Tematik bersama mahasiswa KKN di Desa Sanggrahan bergerak bersama memenuhi keinginan mereka untuk latihan ketoprak. Berkat kerja sama PPM Tematik, mahasiswa KKN ISI Surakarta di Desa Sanggrahan serta dibantu mahasiswa KKN dari desa tetangga serta tokoh masyarakat setempat, khususnya Ki Legawa, latihan dapat dilakukan dengan baik. Latihan dapat terlaksana dengan baik karena ada pembagian tugas yang jelas sesuai dengan kompetensinya. Misalnya Ki Legawa dan 
beberapa mahasiswa menyusun naskah lakon, dan menyiapkan para pemain, sedangkan iringan musik dibantu oleh mahasiswa KKN ISI Surakarta yang bertugas di kecamatan yang berbeda. Kerjasama antara Ki Legawa, mahasiswa KKN, pelaku PPM Tematik (2018), beberapa tokoh masyarakat, dan pemuda Karang Taruna menghasilkan produk balungan lakon dan sebuah pertunjukan ketoprak dengan lakon Manunggal. Adapun pertunjukan ketoprak Taruna Budaya dengan lakon Manunggal diselenggarakan pada 27 Agustus 2018 dalam acara peringatan HUT Kemerdekaan Indonesia yang ke 73 dan perpisahan Mahasiswa KKN dengan warga Desa Sanggrahan.

PPM Tematik bekerja sama dengan Mahasiswa KKN berhasil mewujudkan keinginan warga desa Sanggrahan yaitu membangkitkan kembali kesenian ketoprak Taruna Budaya. Namun demikian sesungguhnya kebangkitan kesenian ketoprak di Desa Sanggrahan tersebut dapat dikatakan masih merupakan tahap awal yang harus ada tindak lanjutnya karena belum bisa mandiri. Group ketoprak ini masih sangat membutuhkan pendampingan yang serius, masih perlu ditata ulang dengan manajemen yang baik, dan masih banyak kebutuhan yang harus dipenuhi. Oleh karena itu melalui artikel ini penulis menghimbau kepada pihak terkait supaya memberi perhatian kepada kesenian ketoprak Taruna Budaya Desa Sanggrahan.

\section{MASA DEPAN KETOPRAK TARUNA BUDAYA}

Menurut pengetahuan penulis, bahwa ketoprak Taruna Budaya belum dapat sepenuhnya disebut sebagai group ketoprak dalam arti yang sebenarnya. Ketoprak selalu berpijak pada tradisi Jawa, karena ketoprak sesungguhnya lahir di Jawa yang meliputi DIY, Jawa Tengah, dan Jawa Timur. Dengan demikian ketoprak merupakan kesenian tradisional khas Jawa. Oleh karena kesenian ketoprak merupakan kesenian khas Jawa maka secara otomatis tradisi yang digunakan sebagai pijakan adalah tradisi Jawa. Tradisi Jawa yang dimaksud meliputi bahasa Jawa dan unggahungguh yang digunakan, serta tembang macapat. Adapun lakon-lakon yang dipertunjukkan berkisar pada cerita rakyat, legenda, sejarah Jawa dan cerita fantasi dari manca negara (Parsi, India, Cina). Sedangkan kostumnya menyesuaikan dengan lakon yang dimainkan (https://slbnlbantul2015.wrodpress/ seni-pertunjukan/ketoprak/). Menurut pengamatan penulis secara langsung di lapangan bahwa para pemain ketoprak Taruna Budaya belum menguasai bahasa Jawa secara baik, juga belum menguasai Tembang Macapat.

Berdasarkan uraian singkat di atas dapat dikatakan bahwa ketoprak Taruna Budaya akan bisa menjadi sebuah group ketoprak dalam arti yang sebenarnya maka perlu mendapat pendampingan secara sungguh-sungguh dalam penguasaan bidang bahasa Jawa dan unggah-ungguh-nya serta penguasaan tembang macapat. Tembang macapat merupakan bagian penting pada sebuah pertunjukan ketoprak, karena bisa menjadi bumbu sehingga pertunjukkan menjadi terasa indah. Tembang macapat ini biasanya digunakan pada adegan tantang-tantangan dan adegan percintaan khususnya pada adegan rungruman (rayuan). Jika proses pendampingan dilakukan secara sungguhsungguh niscaya akan menghasilkan group ketoprak dalam arti yang sebenarnya.

\section{KESIMPULAN}

Kesenian tradisional ketoprak merupakan salah satu hasil olah budaya bangsa yang kehadirannya masih dinanti-nantikan oleh masyarakat pendukungnya. Begitu pula dengan masyarakat Desa Sanggrahan yang berjuang untuk menghadirkan atau menghidupkan kembali kesenian ketoprak yang sedang mengalami mati suri.

Kehadiran mahasiswa KKN dan PPM Tematik ISI Surakarta (2018) di Desa Sanggrahan mampu mewujudkan keinginan masyarakat Desa Sanggrahan untuk menghidupkan kembali kesenian 
ketoprak yang sedang mati suri itu. Seturut perjalanan waktu kesenian ketoprak di Desa Sanggrahan telah bangkit kembali, namun demikian masih membutuhkan pendampingan secara sungguhsungguh dari pihak-pihak yang berkompeten. Pendampingan itu penting karena group ketoprak di Desa Sanggrahan masih banyak kekurangannya, baik menyangkut teknis maupun praksis. Oleh karena itu dapat dipastikan bahwa tanpa pendampingan kesenian ketoprak di Desa Sanggrahan akan tenggelam dan akhirnya mati.

\section{DAFTAR PUSTAKA}

Bambang Suwondo, 1981. Adat Istiadat Daerah Istimewa Yogyakarta. Yogyakarta: Proyek Penelitian dan Pencatatan Kebudayaan Daerah Pusat Penelitian Sejarah dan Budaya Depatemen Pendidikan dan Kebudayaan.

Edi Sedyawati, 1981. Pertumbuhan Seni Pertunjukan. Jakarta: Sinar Harapan.

Heniy Astianto, 2006. Filsafat Jawa, Menggali Butit-butir Kearifan Lokal. Yogyakarta : Warta Pustaka.

Maria A Sardjono, 1992. Paham Jawa. Jakarta: Pustaka Sinar Harapan.

Ramdani Wahyu, 2007. ISD (Ilmu Sosial Dasar). Bandung: Pustaka Setia.

Sumanto, 2004. Reaktualisasi Nilai Budaya Jawa Dalam Buaya Global, dalam LAKON Jurnal Ilmu dan Seni, STSI Surakarta Vol. 1 No. 2 Desember 2004.

Umar Kayam, 1981. Seni, Tradisi, Masyarakat. Jakarta: Sinar Harapan
Muhammad Naufal Fawwaz dkk. 2017. Laporan Kegiatan Kuliah Kerja Nyata (KKN) di Desa Sanggrahan Kecamatan Kranggan Kabupaten Temanggung.

\section{NARA SUMBER}

1. Legawa (63 tahun), seniman dalang wayang kulit purwa, budayawan dari Dusun Rowo Wetan, Desa Sanggrahan.

2. Jumianto (62 tahun), mantan pemain ketoprak Sapta Budaya yang kini menjabat sebagai Kadus Rowo Wetan.

3. Jupriyono, menjabat sebagai Sekdes (Carik) Desa Sanggrahan, dan

4. Pawit (58 tahun) pemain ketoprak yang biasanya berperan sebagai pelawak.

\section{SUMBER INTERNET}

NN.2015 K : https://slbn lbantul20155.wordpress. com/seni-pertunjukan/ketoprak/

Srikandi Rahayu. 2015. Seputar Pengertian Ketoprak.http://seputarpengertian. blogspot.com/2015/04/seputarpengetian-kesenian-ketoprak.html. 2015. Pengertian dan Unsur Teater. http://seputarpegertian.blogspot.com/ 2015/03/pengertian-dan-unsurteater.html. http://belajar.kemdikbud.go.id/ Respositori/ketoprak/

NN. https://slbn1bantul2015.wrodpress/senipertunjukan/ketoprak/ 